\title{
KARAKTERISTIK DAN KEBUTUHAN ANAK BERKEBUTUHAN KHUSUS
}

\author{
${ }^{(1)}$ Khairun Nisa, ${ }^{(2)}$ Sambira Mambela dan ${ }^{(3)}$ Lutfi Isni Badiah \\ ${ }^{(1)}$ Mahasiswa ${ }^{(2,3)}$ Dosen Pogram Studi Pendidikan Khusus \\ FKIP Universitas PGRI Adi Buana Surabaya \\ Email: ${ }^{(1)}$ Khairunnisa@gmail.com, ${ }^{(2)}$ Sam.Mambela@gmail.com , ${ }^{(3)}$ Lutfiisnibadiah@gmail.com
}

\begin{abstract}
ABSTRAK
Anak-anak berkebutuhan khusus (ABK) adalah anak-anak yang tumbuh dan berkembang dengan berbagai perbedaan dengan anak-anak pada umumnya. Istilah anak-anak dengan kebutuhan khusus tidak mengacu pada sebutan untuk anak-anak penyandang cacat, tetapi mengacu pada layanan khusus yang dibutuhkan anak-anak dengan kebutuhan khusus. Ada berbagai jenis kategori dalam lingkup jangka waktu anak-anak dengan kebutuhan khusus. Dalam konteks pendidikan khusus di Indonesia, anak-anak dengan kebutuhan khusus dikategorikan dalam hal anak-anak tunanetra, anak-anak tuna rungu, anak-anak dengan kecacatan intelektual, anak-anak penyandang cacat motorik, anak-anak dengan gangguan emosi sosial, dan anak-anak dengan bakat cerdas dan khusus. Setiap anak dengan kebutuhan khusus memiliki karakteristik berbeda dari satu ke yang lain. Selain itu, setiap anak dengan kebutuhan khusus juga membutuhkan layanan khusus yang disesuaikan dengan kemampuan dan karakteristik mereka. Penting untuk melaksanakan kegiatan identifikasi dan penilaian untuk mengidentifikasi karakteristik dan kebutuhan mereka. Hal ini dianggap penting untuk mendapatkan layanan yang tepat sesuai dengan karakteristik, kebutuhan dan kemampuannya.
\end{abstract}

Kata kunci: Karakteristik, Kebutuhan, Anak Berkebutuhan Khusus

\section{ABSTRACT}

Children with special needs $(A B K)$ are children who grow and develop with various differences with children in general. The term of children with special needs does not refer to the designation for children with disabilities, but refers to the special services that children with special needs need. There are various types of categories within the scope of the term of children with special needs. In the context of special education in Indonesia, children with special needs are categorized in terms of children with visual impairment, deaf children, children with intelectual disability, children with motoric disabilities, children with social emotional disorder, and children with intelligent and special talents. Each child with special needs has different characteristics from one to another. Moreover, each child with special needs also needs special services tailored to their abilities and characteristics. It is necessary to carry out identification and assessment activities to identify their characteristics and needs. It is considered important to get the right service according to the characteristics, needs and abilities.

Keyword: Characteristic, Needs, Children with Special Needs

\section{PENDAHULUAN}

Anak berkebutuhan khusus (ABK) menjadi sorotan masyarakat maupun pemerintah selama hampir satu dekade terakhir. Baik dari segi layanan pendidikan, layanan terapi, aksesibilitas umum, dan berbagai hal terkait dengan pemenuhan hak bagi ABK. Terbaru, berbagai layanan dan pemenuhan hak untuk ABK saat ini pun telah tertuang dalam UU No.8 Tahun 2016. Bahkan, pemerintah saat ini sedang gencar menggalakkan pendidikan dan lingkungan yang ramah bagi ABK. Hal tersebut diwujudkan oleh pemerintah dalam bentuk pendidikan inklusif serta mulai diperketatnya bangunan-bangunan dan fasilitas umum yang 
harus memenuhi standar aksesibilitas bagi ABK.

Secara sederhana, anak berkebutuhan khusus dapat diartikan sebagai anak yang memerlukan layanan khusus untuk dapat menjalani aktivitas sehari-hari dengan baik. Hal tersebut mencakup anak-anak yang mengalami permasalahan maupun yang memiliki kelebihan terkait tumbuh kembang yang kaitannya dengan intelegensi, inderawi, dan anggota gerak. Seperti yang diungkapkan oleh Efendi (2006) bahwa anak berkebutuhan khusus merupakan suatu kondisi yang berbeda dari rata-rata anak pada umumnya. Perbedaan dapat berupa kelebihan maupun kekurangan. Dari adanya perbedaan ini, akan menimbulkan berbagai akibat bagi penyandangnya. Heward menyatakan bahwa anak berkebutuhan khusus merupakan anak dengan karakteristik khusus yang berbeda dengan anak pada umumnya tanpa selalu menunjukkan pada ketidakmampuan mental, emosi atau fisik (Rejeki \& Hermawan, 2010)

Namun daripada itu, kondisi masyarakat saat ini masih banyak yang belum terbuka dengan ABK. Permaslahan ini menunjukkan budaya masyarakat Indonesia yang masih belum tumbuh menjadi budaya yang inklusif yang ramah dengan ABK. Penulisan artikel ini bertujuan untuk memberikan wawasan kepada pembaca tentang karakteristik setiap jenis $\mathrm{ABK}$ dan bagaimana pemenuhan kebutuhan layanan yang disesuaikan dengan setiap karakteristik mereka.

\section{METODE PELAKSANAAN}

Kegiatan Pengabdian Kepada Masyarakat di PK-PLK Cinta Ananda Kabupaten Sumenep dilaksanakan dengan memberikan materi tentang:

1. Klasifikasi Anak Berkebutuhan Khusus, dijelaskan klasifikasi anak berkebutuhan khusus terdiri dari Anak dengan gangguan penglihatan, pendengaran, intelegensi, fisik dan motorik, pervasif.

2. Karakteristik Anak Berkebutuhan Khusus, dijelaskan tentang masingmasing karateristik khusus dari Anak dengan gangguan penglihatan, pendengaran, intelegensi, fisik dan motorik, pervasif.

Pemberian materi disampaikan oleh Drs. Sambira Mambela, M.Pd dan Lutfi Isni Badiah, S.Pd.,M.Pd pada tanggal 23 Maret 2018. Kegiatan dilaksanakan dengan menyampaikan paparan materi kemudian dilakukan tanya jawab dan diskusi dengan orang tua anak berkebutuhan khusus. Di akhir kegiatan dilakukan pengambilan kesimpulan dari paparan materi tersebut oleh pemateri dan juga oleh peserta.

\section{HASIL DAN PEMBAHASAN}

\section{A. Karakteristik dan Kebutuhan ABK}

\section{Tunanetra}

Istilah anak tunanetra secara mendasar dapat diartikan sebagai anak-anak yang mengalami gangguan pada fungsi penglihatan. Kita perlu mendefinisikan ketunanetraan berdasarkan fungsi atau kemampuan penglihatan yang tersisa. Hal ini bertujuan untuk membantu mempermudah dalam penyediaan layanan baik dalam bentuk akademik maupun layanan tambahan sebagai keterampilan pendamping. Dengan mendefinisikan ketunanetraan sesuai dengan tingkatan fungsi penglihatan, maka kita tidak akan mengartikan secara mendasar bahwa anak tunanetra adalah anak yang mengalami kebutaan.

Beberapa ahli seperti Djaja Rahardja dan Sujarwanto (2010) serta Gargiulo (2006) mendefinisikan ketunanetraan menjadi 3 kategori yaitu buta buta, buta fungsional dan low vision. Seseorang disebut mengalami kebutaansecara legal jika kemampuan penglihatannya berkisar 20/200 atau dibawahnya, atau lantang pandangannya tidak lebih dari 20 derajat. Pada pengertian ini, seorang anak di tes dengan menggunakan snellen chart (kartu snellen) dimana anak harus dapat 
mengidentifikasi huruf pada jarak 20 kaki atau 6 meter. Dengan pengertian lain anak-anak dikatakan buta secara legal jika mengalami permasalahan pada sudut pandang penglihatan, yaitu kemampuan menggerakkan mata agar dapat melihat ke sisi samping kiri dan kanan.

Seorang anak dikatakan mengalami kebutaan apabila mereka hanya memiliki sedikit persepsi tentang rangsangan cahaya yang diterima atau mungkin tidak mempu mengidentifikasi apapun dengan kemampuan penglihatannya dengan kata lain disebut dengan buta total. Anak-anak pada kategori ini memanfaatkan indera pendegaran dan perabanya sebagai alat utama untuk mendapatkan informasi tentang keadaan disekitar.

Seorang anak dikatakan mengalami buta fungsional apabila mereka memiliki sisa penglihatan untuk mengidentifikasi cahaya disekitar. Anak-anak pada kategori ini masih mampu mengidentifikasi stimulus cahaya di lingkungan sekitar. Beberapa dari mereka masih mampu mengidentifikasi pantulan cahaya dari benda-benda disekitar, sehingga dengan adanya sisa penglihatan ini dapat memudahkan mereka untuk belajar orientasi mobilitas.

Sedangkan anak dikatakan low vision apabila mereka masih memiliki sisa penglihatan untuk berorientasi dengan lingkungan sekitar. Bahkan, anak-anak low vision masih mampu mengidentifikasi huruf dan angka dengan kata lain dapat digunakan untuk membaca meskipun membutuhkan bantuan kaca pembesar. Pada kategori ini, anak yang mengalami low vision masih mampu mengidentifikasi wajah seseorang dengan kemampuan penglihatannya meskipun pada jarak yang sangat dekat.

Berdasarkan pengertian tersebut dapat kita simpulkan bahwa anak-anak tunanetra adalah anak yang mengalami permasalahan pada fungsi penglihatannya, sehingga mereka mengalami permasalahan dalam berorientasi dengan lingkungan melalui indera penglihatannya. Tentunya anak yang mengalami ketunanetraan akan menglami permasalahan dalam proses belajarnya, berbeda dengan anak normal yang dapat menerima informasi dari indera penglihatannya. Maka dalam hal ini anak tunanetra membutuhkan layanan khusus dalam proses belajarnya. Secara umum, anak tunanetra harus belajar dengan menggunakan tulisan braille, yaitu dengan memanfaatkan indera perabanya untuk mengidentifikasi tulisan braille. Meskipun demikian, anak-anak tunanetra juga dilatihkan memanfaatkan sisa penglihatannya untuk berorientasi dengan lingkungan sekitar, misalnya yang mengalami buta fungsional, mereka harus mampu memanfaatkan sisa penglihatannya untuk membantu mereka dalam proses belajar orientasi mobilitas. Sedangkan anak low vision juga harus dikenalkan dengan tulisan awas sehingga tidak terbatas belajar dengan tulisan braille.

Selain membutuhkan tulisan braille untuk dapat belajar, anakanak dengan ketunanetraan juga memerlukan pendekatan yang berbeda pada proses belajarnya. Guru perlu menggunakan media pembelajaran yang mirip dengan bentuk nyata (tiruan,replika), sehingga anak tunanetra dapat memanfaatkan indera perabanya untuk membantu mendapatkan informasi dalam kegiatan 
belajarnya. Namun demikian, anak tunanetra juga perlu pengalaman nyata untuk memperluas pengetahuan dan mempermudah proses belajar seperti halnya anakanak pada umumnya.

Lebih daripada itu, dalam lingkungan masyarakat anak-anak perlu bantuan aksesibilitas untuk dapat memanfaatkan fasilitas umum yang tersedia. Sebagai contoh trotoar atau lantai yang dilengkapi dengan bidang timbul yang dapat memudahkan mereka untuk mengidenfi arah mereka berjalan. Selain itu diperlukan pula, tulisantulisan braile yang terpasang pada ruang umum untuk memudahkan mereka dalam menemukan fasilitas yang mereka perlukan.

\section{Tunarungu}

Tunarungu dapat diartikan sebagai gangguan pendengaran, dimana anak yang mengalami ketunarunguan adalah menglami permasalahan pada hilangnya atau berkurangnya kemampuan pendengaran. Andreas Dwijosumarto (dalam Soemantri, 2007) menyatakan bahwa anak yang dapat dikatakan tunarungu jika mereka tidak mampu atau kurang mampu mendengar. Menurutnya, tunarungu dapat dibedakan menjadi dua kategori yaitu tuli dan kurang dengar. Tuli merupakan suatu kondisi dimana seseorang benarbenar tidak dapat mendengar dikarenakan hilangnya fungsi dengar pada telinganya. Sedangkan kurang dengar merupakan kondisi dimana seseorang yang mengalami kerusakan pada organ pendengarannya tetapi masih dapat berfungsi untuk mendengar meskipun dengan atau tanpa alat bantu dengar.

Sedangkan Boothroyd (dalam Winarsih, 2007) memiliki padangan berbeda tentang kasifikasi anak tunarungu. Terdapat 4 klasifikasi anak tunarungu yaitu tunarungu ringan (15-30 db), tunarungu sedang (31-60 db), tunarungu berat (61-90 $\mathrm{db}$ ), dan tunarungu sangat berat (91$120 \mathrm{db}$ ).

Dampak secara khusus, hilangnya fungsi dengar pada seseorang dapat mempengaruhi proses komunikasi dengan orang lain. Telinga atau indera pendengar merupakan organ yang berperan sentral dalam proses penerimaan informasi berupa suara, yang kemudian diproses oleh otak sehingga menghasilkan persepsi tertentu. Setiap manusia dapat berkomunikasi dan berbicara secara verbal dikarenakan otak dapat merekam setiap informasi yang diterima oleh telinga sejak usia dini. Dengan demikian, hilangnya fungsi pendengaran sejak usia dini sama saja seorang anak akan mengalami miskin kosakata karena terhambatnya proses masuknya informasi berupa suara melalui telinga (Soemantri, 2007).

Berdasarkan permasalahan tersebut dapat kita simpulkan bahwa pada dasarnya anak tunarungu tidak mengalami hambatan pada perkembangan intelegensi dan aspek-aspek lain, selain yang berkaitan dengan pendengaran dan komunikasi. Oleh karena itu, dalam segi pelayanan pendidikan anak tunarungu memiliki kemampuan yang tidak berbeda dengan anakanak pada umumnya. Namun daripada itu, guru memerlukan metode khusus dalam menyampaikan materi pelajaran kepada anak tunarungu. Guru harus mampu berbicara dengan mimik mulut yang jelas, sehingga meskipun tanpa mendengar anak tunarungu dapat mencerna informasi yang disampaikan. Lebih daripada itu, guru juga harus mampu 
menggunakan bahasa isyarat atau bahasa tubuh untuk membantu proses penyampaian informasi. Metode pembelajaran seperti ini dapat disebut dengan pendekatan Komtal (Komunikasi Total) (Suparno, 1989).

\section{Tunagrahita}

Tunagrahita merupakan istilah yang disematkan bagi anakanak berkebutuhan khusus yang mengalami permasalahan seputar intelegensi. DiIndonesia istilah tunagrahita merupakan pengelompokan dari beberapa anak berkebutuhan khusus, namun dalam bidang pendidikan mereka memiliki hambatan yang sama dikarenakan permasalahan intelegensi. Dalam bahasa asing, anak yang mengalami permasalahan intelegensi memiliki beberapa istilah penyebutan antara $\mathrm{t}$ (IQ dibawah 35). Sedangkan klasifikasi lain dapat didasarkan pada kemampuan yang dimiliki yaitu Ringan (Mampu didik), Sedang (Mampu latih), Berat (Mampu rawat).

Berdasarkan teori-teori tersebut maka kita dapat mengetahui kebutuhan mendasar anak tunagrahita. Dalam proses pembelajran, anak tunagrahita memerlukan pendekatan yang berbeda dengan anak-anak pada umumnya karena kecepatan proses penerimaan pengetahuan tentu lebih lambat. Hal tersebut tentu hanya berlaku bagi anak tunagrahita yang memang masih memeiliki kemampuan untuk menerima pelajaran, dengan kata lain adalah anak tunagrahita mampu didik. Akan tetapi bagi anak tunagrahita yang mampu latih, maka perlunya mereka mendapat latihan-latihan bina diri untuk dapat membantu dirinya lebih mandiri dan tidak bergantung pada orang lain. Sedangkan bagi anak tunagrahita lain mental retardasi, mental defectif, mental defisiensi, dan lainlain (Somantri, 2007).

Berbagai istilah yang digunakan untuk menyebut anak tunagrahita pada dasarnya memiliki arti yang sama, yaitu menjelaskan tentang anak yang memiliki keterbatasan intelegensi di bawah rata-rata sehingga berdampak pada permasalahan akademik dan kesulitan dalam menjalani aktivitas sehari-hari (Somantri, 2007). Anak tunagrahita dapat diklasifikasikan berdasarkan tingkatan intelegensi dengan dasar intelegensi normal manusia dengan Skala Binet berkisar antara 90-110. Adapun klasifikasi berdasarkan tingkat intelegensi adalah Ringan (IQ 6580), Sedang (IQ 50-65), Berat (IQ 35-50), Sangat bera yang memiliki tingkat berat atau sangat berat, mereka memiliki karkateristik lebih khusus dimana mereka akan kesulitan untuk menjalani aktivitas sosial seharihari. Anak-anak pada kategori tersebut membutuhkan bantuan orang lain untuk dapat mengurus dirinya sendiri.

\section{Tunadaksa}

Dalam konteks pendidikan khusus di Indonesia, tunadaksa dapat diartikan sebagai gangguan motorik. Pada konteks lain dapat kita temui penggunaan istilah lain dalam menyebut anak tunadaksa misalnya anak dengan hambatan gerak. Utamanya, anak tunadaksa adalah anak yang mengalami gangguan fungsi gerak yang disebabkan oleh permasalahan pada organ gerak pada tubuh. Somantri (2007) menjelaskan bahwa tunadaksa merupakan suatu keaadan rusak atau terganggu yang disebabkan karena bentuk abnormal atau organ tulang, otot, dan sendi tidak dapat berfungsi dengan baik. 
Pada hakikatnya, anak tunadaksa memiliki berbagai jenis klasifikasi tergantung pada bagian anggota gerak mana yang mengalami permasalahan. Adapun beberapa jenis tunadaksa adalah Club-foot (kaku kai), Club-hand (kaku tangan), Polydactylism (jari lebih banyak), Syndactylism (jari berselaput), Torticolis (gangguan tulang leher), Spina Bifida (abnormalitas sumsum tulang belakang), dll. Pendidikan khusus di Indonesia menggolongkan anak cerebral palsy pada kumpulan anak berkebutuhan khusus tunadaksa. Meskipun termasuk jenis disabilitas Brain Injury, anak cerebral palsy digolongkan dalam anak tunadaksa karena mengalami gangguan pada fungsi gerak terutama pada otot (Somantri, 2007).

Anak tundaksa mengalami gangguan pada anggota gerak, namun pada umumnya anak-anak tunadaksa tidak mengalami permasalahan kemampuan intelegensi. Secara umum, anak tunadaksa mengalami perkembangan normal seperti anakanak pada umumnya. Namun, lebih daripada itu kita perlu lebih memberikan perhatian pada anak tunadaksa dalam segi perkembangan sosial emosional. Anak tunadaksa tumbuh dengan kondisi tubuh yang bermasalah, tentu hal tersebut sedikit banyak akan mempengaruhi perkembangan sosial emosional. Anak tunadaksa rawan akan perilaku minder, menutup diri, dan bahkan rawan bullying.

Dalam proses pembelajaran, anak tunadaksa memerlukan metodemetode khusus yang disesuaikan dengan kondisi tubuh. Tidak setiap anak tunadaksa dapat menulis dengan baik dikarenakan kondisi motorik halus yang tidak memungkinkan. Selain pembelajaran berbasis akademik, anak tunadaksa juga memerlukan pembelajaran-pembelajaran khusus untuk melatih Soft Skill agar dapat memanfaatkan sisa kemampuan atau fungsi gerak untuk dapat menghasilkan karya cipta. Pelayanan-pelayanan tersebut sangat diperlukan anak-anak tunadaksa agar dapat membantu kualitas hidupnya lebih baik dan mandiri.

\section{Tunalaras}

Anak tunalaras merupakan konteks dengan batasan-batasan yang sangat rumit tentang anak-anak yang mengalami masalah tignkah laku. Istilah tunalaras itu sendiri belum dapat diterima secara umum karena batasan-batasan penyebutan anak tunalaras yang kurang saklek. Pada intinya sebutan anak tunalaras merupakan gangguan perilaku yang menunjukan suatu penentangan yang terus menerus pada masyarakat, merusak diri sendiri, serta gagal dalam proses belajar di sekolah (Somantri, 2007). Somantri menambahkan, sebutan lain anak tunalaras yaitu anak tunasosial karena anak tersebut selalu melakukan penentangan terhadap norma dan aturan sosial di masyarakat seperti mencuri, mengganggu ketertiban, melukai orang lain, dll. Kauffman (dalam Somantri, 2007) menyatakan tentang batasan-batasan anak dapat disebut tunalaras jika secara nyata dan menahun merespon lingkungan yang menyimpang tanpa ada kepuasan pribadi namun masih dapat diajarkan perilaku baik.

Dalam konteks pendidikan khusus di Indonesia menyebut anak tunalaras mengalami permasalahan pada perilaku, sosial, dan emosional. Berdasar pada permasalahan tersebut, anak tunalaras dapat mengalami dampak yang sangat besar jika tidak mendapatkan 
layanan secara khusus. anak-anak tunalaras memerlukan layanan konseling dan rehabilitasi untuk menerapkan latihan-latihan secara khusus agar dapat berperilaku sesuai dengan norma dan aturan sosial dalam bermasyarakat.

\section{Anak cerdas dan bakat istimewa} Anak berbakat dan kecerdasan istimewa sesuai undang undang termasuk anak yang memerlukan layanan khusus, hal tersebut tertuang pada UU Sisdiknas No.2 2003. Menurut Somantri (2007) anak berbakat dan cerdas istimewa memiliki kebutuhan dan karakteristik yang berbeda dengan anak-anak pada umumnya. istilah anak berbakat memiliki kesamaan dengan istilah-istilah asing, yang mana dapat diartikan bahwa anak berbakat merupakan anak yang memiliki kemampuan atau talenta di atas rata-rata anak pada umumnya. Serupa dengan anak dengan kecerdasan istimewa yang memiliki kecerdasan di atas IQ rata-rata anak pada umumnya. Namun, terdapat pendapat lain tentang istilah anak berbakat dan cerdas istimewa, yaitu mereka yang memiliki kemampuan atau IQ di atas rata-rata serta dapat berprestasi karena kemampuan tersebut.

Pada umumnya, tumbuh kembang anak dengan kecerdasan dan bakat istimewa sama seperti anak-anak normal. Namun, lebih ditekankan pada perkembangan pada aspek tertentu dimana mereka mengalami perkembangan yang lebih cepat dibanding anak-anak seusianya. Hal tersebut dapat berlaku pada aspek apapun, baik pemahaman tentang ilmu pengetahuan, kinestetik, seni, dll. Oleh karena itu, anak dengan kecerdasan dan bakat istimewa memerlukan layanan khusus untuk menunjang pesatnya perkembangan pada aspek-aspek tertentu.

Anak dengan kecerdasan dan bakat istimewa memang mengalami perkembangan yang cepat pada aspek tertentu, tapi bukan berarti hal tersebut tidak membawa ancaman negatif terhadap aspek sosial emosional mereka. Anak dengan kecerdasan dan bakat istimewa akan mendapat prestasi lebih banyak dan tingkat keberhasilan lebih tinggi dibanding anak lain. Namun tentu dapat berakibat fatal jika mereka mengalami kegagalan, hal yang dapat terjadi adalah menutup diri, stress tinggi, sampai dengan bunuh diri dapat terjadi pada anak dengan kecerdasan dan bakat istimewa yang mengalami kegagalan. Oleh karena itu, selain layanan untuk menunjang kecerdasan dan bakat mereka memerlukan layanan konseling serta pendampingan untuk memperkuat sisi sosial emosional mereka.

\section{KESIMPULAN}

Anak berkebutuhan khusus merupakan anak yang tumbuh dan berkembang dengan berbagai perbedaan dengan anak-anak pada umumnya. Sebutan anak berkebutuhan khusus tidak selalu merujuk pada kecacatan yang dialami, namun merujuk pada layanan khusus yang dibutuhkan karena mengalami suatu hambatan atau kemampuan diatas ratarata. Meskipun jenis anak berkebutuhan khusus sangat beragam, namun dalam konteks pendidikan khusus di Indonesia anak berkebutuhan khusus di kategorikan dalam istilah anak tunanetra, anak tunarungu, anak tunagrahita, anak tunadaksa, anak tunalaras, dan anak cerdas dan bakat istimewa.

Setiap anak berkebutuhan khusus memiliki karakteristik yang berbeda-beda antara satu dengan yang lain. Layanan untuk anak berkebutuhan khusus tidak dapat disamakan antara satu dengan yang lain, akan tetapi perlu diberikan sesuai dengan karakteristik kebutuhan dan kemampuan mereka. Untuk mendapatkan layanan yang sesuai dengan karakteristik kebutuhan dan 
kemampuannya, perlu dilakukan identifikasi dan asesmen terhadap anak berkebutuhan khusus. Berbagai bentuk layanan perlu diberikan untuk menunjang kebutuhan mereka, tidak hanya pada bidang pendidikan namun layanan non akademik juga sangat diperlukan untuk meningkatkan kualitas hidup mereka menjadi lebih baik dan mandiri.

\section{REFERENSI}

Efendi, M. (2006). Pengantar Psikopedagogik Anak Berkelainan. Jakarta: PT. Bumi Aksara

Gargiulo, Richard M. 2012. Special Education in Contemporary Society: An Introduction Exceptionality. Betty Nelson. USA: Sage Publication Maternal Reflection Metod. Swetz \& Zeitlinger. Amsterdam \& Lisse. Holland

Rahardja, Djaja \& Sujarwanto. 2010. Pengantar Pendidikan Luar Biasa. Surabaya: UNESA

Rejeki, D.S. \& Hermawan. 2010. Pendidikan Inklusi dan Kemampuan Menyesuaikan Diri Anak Berkebutuhan Khusus Terhadap Keberhasilan Sosialisasi. Jurnal pendidikan dan Kebudayaan, Vol. 16, Edisi Khusus II.

Soemantri, Sutjihati. 2007. Psikologi Anak Luar Biasa. Bandung: Reflika Aditama

Winarsih, Murni. 2007. Intervensi Dini Bagi Anak TunarunguDalam Pemerolehan Bahasa. DEPDIKNAS

Sunardi dan Sunaryo. 2007. Intervensi Dini Anak Berkebutuhan Khusus. Jakarta : Depdiknas.

Thomas J. Berndt (1997) Parental Socialization Of Positive and Negative Emotions:

Associations With Children's Everyday Coping and Display Rule Knowledge. Dissertation. North Carolina University.

Thomas, R. \& Zimmer-Gembeck, M. (2007). Behavioral outcomes of parent-child interaction therapy and Triple $P$ i Positive Parenting Program: A review and meta-analysis. Journal 